\title{
トンネル掘削に伴う地山変位計測結果の簡易解析法
}

\section{SIMPLE ANALYTICAL METHOD OF GROUND MOVEMENT DURING TUNNEL EXCAVATION}

\author{
足立紀 尚*·矢野隆夫** \\ By Toshihisa ADACHI and Takao YANO
}

\begin{abstract}
This paper presents a simple method to analyze the measured results of tunnel wall convergence and of displacement in the surrounding ground during tunnel excavation. This method is based on the assumptions that a circular tunnel is excavated in a twodimensional ideal elastic body and that the vertical stress is equal to the overburden pressure. We can estimate easily (1) the directions and values of the principal genuine mountain stresses and (2) the elastic shear modulus of the ground from tunnel convergence measurements. In addition to the above (1) and (2), (3) the absolute movement of surrounding ground and (4) the approximate extent of the inelastic zone caused in surrounding ground can be estimated also in the case of the extensometer measurements.

Keywords : tunnel, field measurements, analysis, elastic solution
\end{abstract}

\section{1. 序論}

NATM の導入によって，トンネルにおける現場計測 が常例的となったものの，計測が常に初期の目的を果た しているかどうかは疑問である。これは評価基準がいま だ確立されていないことと同時に，データの簡便な処理 方法の開発が遅れていることに起因していると考えられ る. 本論文では, 解析手法として最近盛んである数値解 析に基づく逆解析手法 ${ }^{1}$ に対し，理論解を用いて準備さ れる図より,トンネルの内空変位計測ならびに地山内変 位計測結果を簡単に解析する一手法を提案する.すなわ ち, 本解析手法はかぶりの深いトンネルを対象として, 二次元理想弾性地山内に円形のトンネルを全断面で掘削 すること，および，初期鉛直応力がかぶり圧に等しいと の仮定に基づき,

（a ）地山の主応力の方向とそれらの值,

（b）地山のせん断弾性係数 $G ，$ またはヤング率 $E$

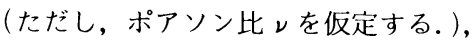
地山内変位計測の場合には，(a)，(b) に加えて,

(c) 地山の絶対変位量,

* 正会員 Ph. D. 京都大学教授 工学部交通土木工学教室 ( ₹606 京都市左京区吉田本町)

** 正会員 京都大学技官 工学部交通土木工学教室 (同上) （d） 非弾性領域の範囲, を容易に推定し得るものである.

なお，本手法の適用にあたって留意すべきことは，鋼 製支保工や吹付けコンクリート設置後の計測において は，それらの支保構造体と地山が一体として働く構造系 の挙動を対象とすることである.すなわち，同一の地山 においても, 支保構造体によっては異なる応力状態 $\left(\sigma_{1}\right.$, $\left.\sigma_{3}\right)$ や地山定数 $(G)$ を推定することになる. しかし逆手 にとらえ, 推定される応力状態や地山定数の変化によっ て, 支保構造の適・不適,また施工の巧拙を判断するデー タとして活用できる可能性もある.

そこで, まず内空変位計测結果の解析方法を, 次いで 地山内変位計測結果の解析方法を論ずることにする.

\section{2. 理想弾性地山中の円形トンネルの解析解}

Fig. 1 に示すような二次元応力場（ $\sigma_{1}$ : その面内の最 大主応力, $\sigma_{3}$ : その面内の最小主応力）の理想弾性地山 内に, 半径 $R$ の円形トンネルを掘削する場合を考える. 最大主応力方向から, 反時計まわりに角度 $\theta$ 方向で, かつ, トンネル中心より距離 $r$ の地点において, トン ネル掘削によって生じる径方向変位 $u_{r}$ 亡接線方向変位 $u_{\theta}$ は次式で与えられる2). 


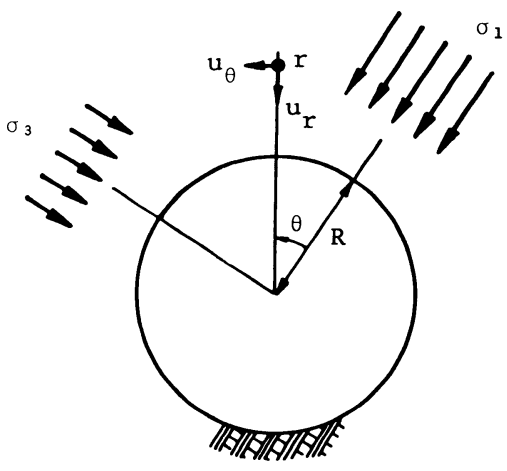

Fig. 1 Stress condition for a circular tunnel.

$u_{r}=\frac{R}{4 G}\left\{\left(\sigma_{1}+\sigma_{3}\right)\left(\frac{R}{r}\right)+\left(\sigma_{1}-\sigma_{3}\right)\left[(1+\chi)\left(\frac{R}{r}\right)\right.\right.$

$\left.\left.-\left(\frac{R}{r}\right)^{3}\right] \cos 2 \theta\right\}$

$u_{\theta}=\frac{R}{4 G}\left(\sigma_{1}-\sigma_{3}\right)\left[(\chi-1)\left(\frac{R}{r}\right)+\left(\frac{R}{r}\right)^{3}\right] \sin 2 \theta$

ここに, $G$ はせん断弾性係数, $\chi$ はポアソン比 $\nu$ の 関数で, 平面ひずみの場合 $\chi=3-4 \nu$ となる.なお, ひずみ量を求める必要があるときは, 式 (1), (2) に 次の関係式を用いればよい。

$$
\left.\begin{array}{l}
\varepsilon_{r}=\frac{\partial u_{r}}{\partial r}, \quad \varepsilon_{\theta}=\frac{u_{r}}{r}+\frac{1}{r} \frac{\partial u_{\theta}}{\partial \theta} \\
\varepsilon_{r \theta}=\frac{1}{2}\left(\frac{1}{r} \frac{\partial u_{r}}{\partial \theta}+\frac{\partial u_{\theta}}{\partial r}-\frac{u_{r}}{r}\right)
\end{array}\right\}
$$

さて, 以降の議論のために, 最大主応力 $\sigma_{1}$ に対する 最小主応力 $\sigma_{3}$ の比を表わすパラメーター $\alpha$

$$
\alpha=\frac{\sigma_{3}}{\sigma_{1}}
$$

を導入し，式（1)，（2）を次式のように書き改めてお $<$.

$$
\begin{aligned}
u_{r}= & \frac{\sigma_{1} R}{4 G}\left\{(1+\alpha)\left(\frac{R}{r}\right)+(1-\alpha)\left[(1+\chi)\left(\frac{R}{r}\right)\right.\right. \\
& \left.\left.-\left(\frac{R}{r}\right)^{3}\right] \cos 2 \theta\right\} \cdots \cdots \cdots \cdots \cdots \cdots \cdots \cdots \cdots \cdots \cdots \cdots \cdots \cdots \cdots \cdots \cdots \\
u_{\theta}= & \frac{\sigma_{1} R}{4 G}(1-\alpha)\left[(\chi-1)\left(\frac{R}{r}\right)+\left(\frac{R}{r}\right)^{3}\right] \sin 2 \theta
\end{aligned}
$$

\section{3. トンネル内空変位計測結果の解析方法 ${ }^{3), 44}$}

トンネルの内空変位計測を Fig. 2 に示すように，天端 の $\mathrm{a}$ 点, 両側壁上の $\mathrm{b}, \mathrm{c}$ 点に計測ピンを設けて行った ものとする. トンネル掘削による各点の変位量は, 式 ( 5 ), (6) に $r=R$ および, $\theta=\theta, \theta=\theta+\pi / 2, \theta=$ $\theta-\pi / 2$ を代入することで以下のように求まる.

$\mathrm{a}$ 点

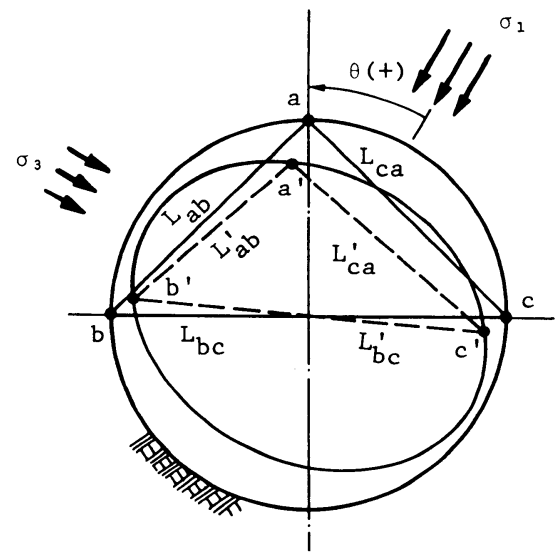

Fig. 2 A circular tunnel and the convergence measurement.

$$
\begin{aligned}
& u_{r \mid a}=\frac{\sigma_{1} R}{4 G}[(1+\alpha)+(1-\alpha) \chi \cos 2 \theta] \\
& u_{\theta \mid a}=\frac{\sigma_{1} R}{4 G}[(1-\alpha) \chi \sin 2 \theta]
\end{aligned}
$$

$\mathrm{b}$ 点

$u_{r \mid b}=\frac{\sigma_{1} R}{4 G}[(1+\alpha)-(1-\alpha) \chi \cos 2 \theta]$

$u_{\theta \mid b}=-\frac{\sigma_{1} R}{4 G}[(1-\alpha) \chi \sin 2 \theta]$

$\mathrm{c}$ 点

$u_{\tau \mid C}=\frac{\sigma_{1} R}{4 G}[(1+\alpha)-(1-\alpha) \chi \cos 2 \theta]$

$u_{\theta \mid c}=-\frac{\sigma_{1} R}{4 G}[(1-\alpha) \chi \sin 2 \theta]$

すなわち,この変位量分だけ $a, b, c$ 点は $a^{\prime}, b^{\prime}, c^{\prime}$ 点 へと変形することになる. 計測される内空変位量 $\Delta L_{a b}$, $\Delta L_{b c}, \Delta L_{c a}$ は上記の変位量を用いて次のように求まる. ただし，計測は切羽後方でのみ可能であるから，実際に は計測開始時に $\mathrm{a}, \mathrm{b}, \mathrm{c}$ 点はすでに変形して棈円上にあ ることになり，ここでの扱いは近似的なものであること を留意すべきである.

$$
\begin{aligned}
\Delta L_{a b}= & L_{a b}-L_{a b}^{\prime}=\sqrt{2} R-\left\{2 R^{2}+2\left(\frac{\sigma_{1} R}{4 G}\right)^{2}\right. \\
& \cdot\left[(1+\alpha)^{2}-2\left(1-\alpha^{2}\right) \chi \sin 2 \theta+(1-\alpha)^{2} \chi^{2}\right] \\
& \left.-4 R\left(\frac{\sigma_{1} R}{4 G}\right)[(1+\alpha)+(1-\alpha) \chi \sin 2 \theta]\right]^{1 / 2}
\end{aligned}
$$

$$
\begin{aligned}
\Delta L_{b c}= & L_{b c}-L_{b c}^{\prime}=2 R-\left\{4 R^{2}+4\left(\frac{\sigma_{1} R}{4 G}\right)^{2}\right. \\
& \cdot\left[(1+\alpha)^{2}-2\left(1-\alpha^{2}\right) \chi \cos 2 \theta+(1-\alpha)^{2} \chi^{2}\right] \\
& \left.-8 R\left(\frac{\sigma_{1} R}{4 G}\right)[(1+\alpha)-(1-\alpha) \chi \cos 2 \theta]\right\}^{1 / 2}
\end{aligned}
$$




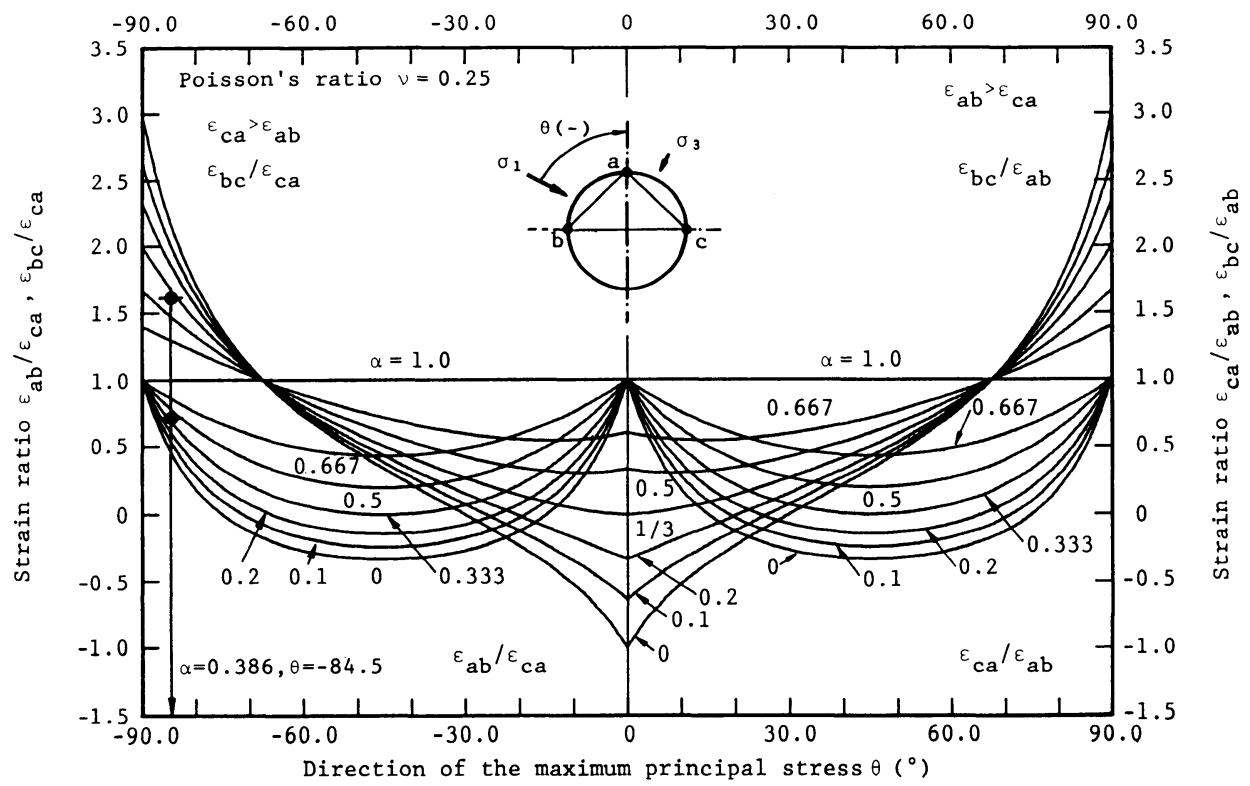

Fig. 3 Relationship between strain ratio and direction of the maximum principal stress.

$$
\begin{aligned}
\Delta L_{c a}= & L_{c a}-L_{c a}^{\prime}=\sqrt{2} R-\left\{2 R^{2}+2\left(\frac{\sigma_{1} R}{4 G}\right)^{2}\right. \\
& \cdot\left[(1+\alpha)^{2}-2\left(1-\alpha^{2}\right) \chi \sin 2 \theta+(1-\alpha)^{2} \chi^{2}\right] \\
& \left.-4 R\left(\frac{\sigma_{1} R}{4 G}\right)[(1+\alpha)-(1-\alpha) \chi \sin 2 \theta]\right\}^{1 / 2}
\end{aligned}
$$

さて，ここで各点間のひずみ量を以下のように定義づ けておく

$$
\begin{aligned}
& \varepsilon_{a b}=\Delta L_{a b} / L_{a b}=\Delta L_{a b} / \sqrt{2} R \\
& \varepsilon_{b c}=\Delta L_{b c} / L_{b c}=\Delta L_{b c} / 2 R \\
& \varepsilon_{c a}=\Delta L_{c a} / L_{c a}=\Delta L_{c a} / \sqrt{2} R
\end{aligned}
$$

序論で述べたように，内空変位計測から決定すべき未 知量は最大主応力 $\sigma_{1}$, 主応力比 $\alpha$, 最大主応力の方向, ならびにせん断弾性係数 $G$ の 4 個である.それらを以 下順次決定していく．Fig. 2 のように， $\sigma_{1}$ の作用方向か ら $\theta(+)$ に鉛直方向がある場合（ $\sigma_{1}$ 方向が鉛直方向から 図に向かって右側）には，変形のモードから明らかなよ うに $\varepsilon_{a b}>\varepsilon_{c a}$ となり，逆に鉛直方向が $\sigma_{1}$ 方向から $\theta(-)$ の場合には $\varepsilon_{a b}<\varepsilon_{c a}$ となる.この事実に着目して，次の ようにひずみの正規化を行う（以下，ひずみ比という）.

$$
\varepsilon_{b c} / \varepsilon_{a b}, \varepsilon_{c a} / \varepsilon_{a b} \quad\left(\varepsilon_{a b}>\varepsilon_{c a} \text { の場合 }\right)
$$

$\varepsilon_{b c} / \varepsilon_{c a}, \varepsilon_{a b} / \varepsilon_{c a} \quad\left(\varepsilon_{a b}<\varepsilon_{c a}\right.$ の場合 $)$

ひずみ比と鉛直方向と最大主応力方向の成す角度 $\theta$ との関係は, ポアソン比 $\nu$ を与え主応力比 $\alpha$ をパラメ一 ターに用いると， $\nu=0.25$ の場合には Fig. 3 のように求 まる.この図を用いることで, まず最大主応力の方向 $\theta$ と主応力比 $\alpha$ が決定できるが，以下 Table 1 に示す,
あるトンネルの場合を例題として説明する.なお，この トンネルは全断面で，支保部材としては吹付けコンク リートのみを適用して掘削されたものであって，断面は Table 1 中に示すように円形ではないが, 円形断面と仮 定して扱うことにする.

(1) Table 1 に示す計测結果より, $\varepsilon_{c a}>\varepsilon_{a b}$ であるか ら $\theta$ は負, すなわち, $\sigma_{1}$ 方向は鉛直方向の左側にあって, 解析にはFig. 3 の左半分を用いることになる。なお， $=0.25$ を仮定したから Fig. 3 が適用できる.

(2) $\varepsilon_{b c} / \varepsilon_{c a}=1.628, \varepsilon_{a b} / \varepsilon_{c a}=0.721$ と与えられ， Fig. 3 において, 双方の值を同時に満足する主応力比 $\alpha$ と角度 $\theta$ の組合せを図中で読み取ると， $\alpha=0.386, \theta=$ $-84.5^{\circ}$ と求まる. すなわち, 最大主応力 $\sigma_{1}$ は鈆直方向 より左へ $84.5^{\circ}$ の方向から作用し, 最小主応力 $\sigma_{3}$ は $\sigma_{1}$

Table 1 Condition of a tunnel and the results of convergence.

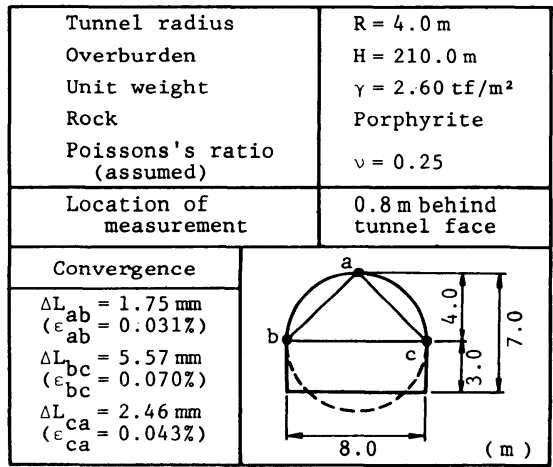


の 0.386 倍である. ただし， $\alpha, \theta$ の決定はプログラム 化されているため, 有効数字 3 桁以上与えているが， あ くまで参考例であると理解されたい.

一般に, 最大主応力 $\sigma_{1}$ の方向 $\theta$ と主応力比 $\alpha$ が与え られると, Fig. 4 に示す, 長半径を $l$, 短半径を $\alpha$ とす る応力楕円が求まる．棈円の鉛直方向の半径 $\rho$ は,

$$
\rho=\frac{l}{\sqrt{\cos ^{2} \theta+\sin ^{2} \theta / \alpha^{2}}}
$$

となり, 鉛直応力 $\sigma_{v}$ はかぶり圧 $\gamma H$ に等しいと仮定す れば，面内における最大，最小主応力値は次のように決 定できる.

$$
\sigma_{1}=\sigma_{v} / \rho=\gamma H / \rho, \quad \sigma_{3}=\alpha \sigma_{v} / \rho=\alpha \gamma H / \rho
$$

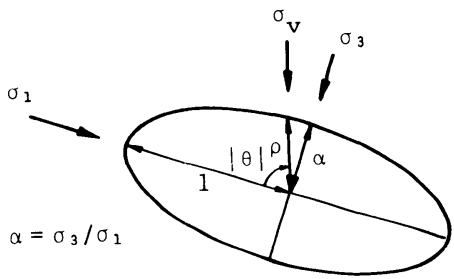

Fig. 4 Determination of the stress values.

(3) 当該トンネルの場合, $\rho=0.388, \sigma_{v}=\gamma H=546$ $\mathrm{tf} / \mathrm{m}^{2}$ であるから， $\sigma_{1}=1407 \mathrm{tf} / \mathrm{m}^{2} ， \sigma_{3}=543 \mathrm{tf} / \mathrm{m}^{2}$ 之求 まる．残る未知量はせん断弾性係数 $G$ である。 $G$ は式 (10)，(11)，(12）のいずれかにより決定できるが，式 （10）を $\sigma_{1} / G$ について解いて求まる次の有意の解を用 いることができる。

$$
\frac{\sigma_{1}}{G}=4\left\{\frac{B-\sqrt{B^{2}-4 A C}}{2 A}\right\} \text {. }
$$

$$
\text { ここに, }
$$

$$
\begin{aligned}
& A=\left[(1+\alpha)^{2}-2\left(1-\alpha^{2}\right) \chi \sin 2 \theta+(1-\alpha)^{2} \chi^{2}\right] \\
& B=2[(1+\alpha)+(1-\alpha) \chi \sin 2 \theta] \\
& C=1-\left(1-\frac{\Delta L_{a b}}{\sqrt{2} R}\right)^{2}=1-\left(1-\varepsilon_{a b}\right)^{2}
\end{aligned}
$$

(4) $\alpha, \chi, \theta$ を式 (20), (21) に用いると, $\sigma_{1} / G=$ $1.08 \times 10^{-3}$,さらに, $\sigma_{1}=1407 \mathrm{tf} / \mathrm{m}^{2}$ を与えて,$G=$ $1.30 \times 10^{6} \mathrm{tf} / \mathrm{m}^{2}$ と求まる.

以上，ポアソン比 $\nu を 0.25$ と仮定できる場合を論じ たが, 最大主応力 $\sigma_{1}$, 主応力比 $\alpha, \sigma_{1}$ の方向 $\theta$ および, せん断弾性係数 $G$ がポアンン比 $\nu$ によりいかに影響を 受けるかを当該トンネルの場合に検討すると，Fig. 5 の 結果を得た。すなわち，応力の作用方向 $\theta$ はポアソン

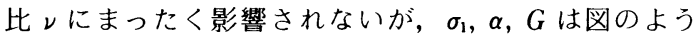
に影響を受けることがわかる。

さて，(4)でせん断弾性係数 $G$ を求めた。しかし，己

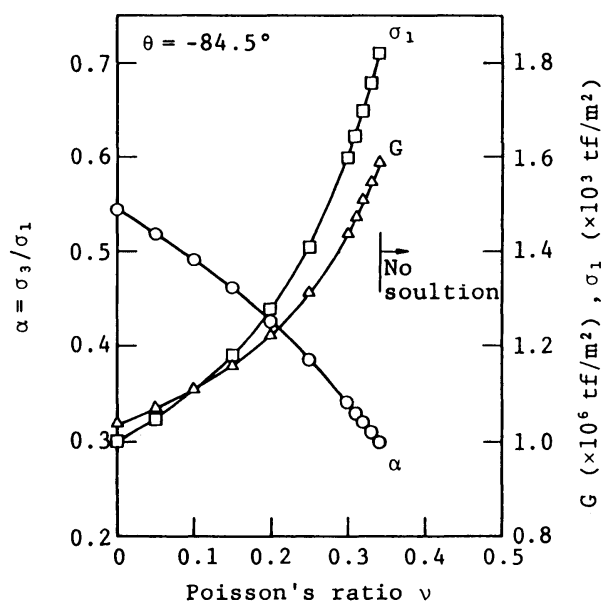

Fig. 5 Dependency of $\sigma_{1}, \alpha$ and $G$ on $\nu$.

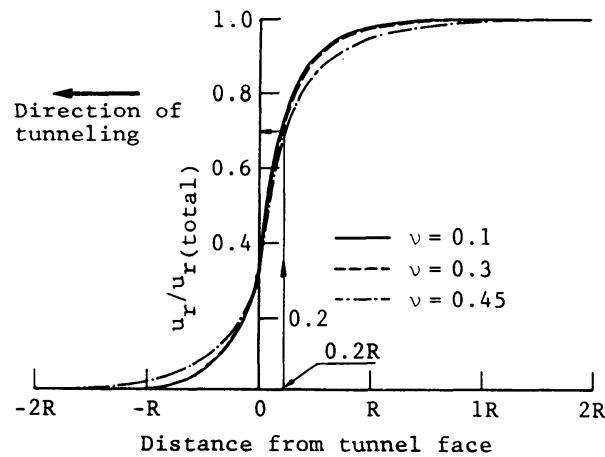

Fig. 6 Relationship between the displacement and the location from tunnel face.

の值は計測結果がトンネル掘削により生じる全変位量に 相当するとしたときの値であるから，補正を施す必要が ある. すなわち, 内空変位計測は切羽後方で行われるた め, 計測開始時には周知の関係図である Fig. 6 に示すと おり，全変位量の何\%かはすでに発現しており，計測さ れる量はそれ以後の切羽進行による残りの変位である. そこで，Gの補正に Fig. 6 の適用を考える. 式 $(7)$, から変位 $u_{r}$ は応力 $\sigma_{1}$ に比例することから, Fig. 6 は切 羽進行による作用応力の変化と考えてよい，すなわち， 計測変位量は残り何\%かの応力増加分に対応していると 考えるわけである.

(5)該当トンネルの場合, 計測は切羽後方 $0.8 \mathrm{~m}$ $(=0.2 R)$ で行われた. Fig. 6 において, 計測開始時 にはすでに $70 \%$ の応力が発揮されており，残りは 30 $\%$ 之読み取れる。すすなわ，0.3 $\sigma_{1}$ に対する変位量が 計測されたことになる。したがって，式（20）が成立す るには，真のせん断弾性係数 $G^{*}$ は先に求まった值の 
$30 \%, 0.3 G$ とする必要がある.よって, 補正された 真のせん断弾性係数 $G^{*}$ は $0.3 G=3.90 \times 10^{5} \mathrm{tf} / \mathrm{m}^{2}$ とな る.なお，ヤング率 $E$ は $E^{*}=2(1+\nu) G^{*}$ を用いて, $E^{*}=9.75 \times 10^{5} \mathrm{tf} / \mathrm{m}^{2}$ と与えられる.

以上,内空変位計測の簡易解析方法について述べたが, 変位挙動は弾性的であるとの前提に立脚していることを 忘れてはならない。この制約はあるものの，以下のよう な利用を検討することは無意味ではない，たとえば，同 一地質，同一応力場と考えられる場合に，場所によって $\sigma_{1}, \alpha, \theta$ ，また， $G^{*}$ が変化したとすれば，これは明ら かに施工の巧拙によるものと判断できる。これらの值と 支保工パターンや，施工手順の関係が明らかになれば, 有意の施工管理手法を確立する可能性があるが，この問 題は今後の検討課題であろう.

\section{4. 地山内変位計測結果の解析方法 ${ }^{5), 6)}$}

地下発電所等の巨大地下空洞の建設に際しては常例的 に, 場合によってはトンネルにおいても地山内変位計測 を実施する，本節においては，序論で述べたように地山 内変位計測結果の解析手法とその適用例を, 初期応力場 が静水圧的である場合と，二次元的である場合に分けて 説明する. ここで，2つに場合分けをしたのは段階を追 う方が，理解が容易になると考えたからである。

\section{（1）初期地山応力が静水圧的である場合}

a) 解析方法

初期地山応力が静水圧的である場合はもとより，地中 変位計 1 本で, なおかつ, 1 方向の計測結果しかない場 合にはこの手法による. 初期地山応力が静水圧的, すな わち, $\sigma_{1}=\sigma_{3}=p_{0}=\gamma H$ であって, $\alpha=1$ であるから,

Fig. 1 の $r$ 点の変位成分 $u_{r}, u_{\theta}$ は式（5)，（6）によ り直ちに次式のように与えられる.

$$
u_{r}=\frac{p_{0}}{2 G} \frac{R^{2}}{r}, u_{\theta}=0
$$

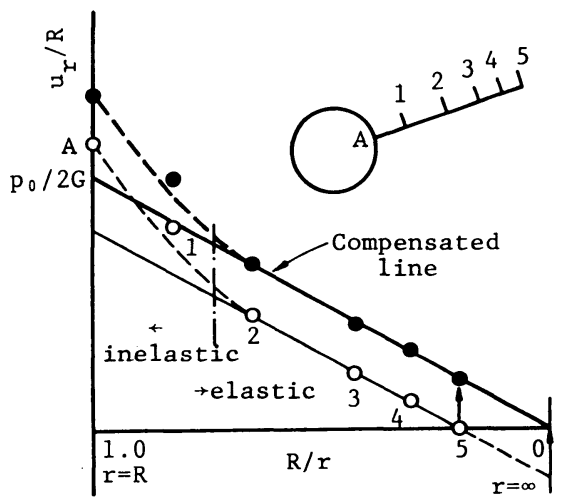

Fig. 7 Expression of measured results and compensation for absolute displacement.
接線方向変位 $u_{\theta}$ は常にゼロであるから, 径方向変位 $u_{r}$ のみが生じることになる. さて, 式 (22) 1 の両辺を トンネル半径 $R$ で除すと, 次式が求まる7).

$$
\frac{u_{r}}{R}=\frac{p_{0}}{2 G}\left(\frac{R}{r}\right)
$$

この式は地山が弾性的に挙動するならば， $u_{r} / R$ が $R / r$ に比例すること, かつ, $r=R$ ，すなわち，トンネ ル壁面の值 $u_{r} /\left.R\right|_{r=R}$ は $p_{0} / 2 G$ に等しいことを意味し ている.

議論を簡単にするために，トンネル掘削前に Fig. 7 中 に模式的に示すように地山内変位計を設置して，トンネ ル掘削に伴う変位量 $u_{r}$ を $\mathrm{A}, 1, \cdots \cdots 5$ の各点で計測し たところ，Fig.7を得たとする．なお，Fig. 7の縦軸に は $u_{r} / R$ を，横軸には $R / r$ をとるが，横軸の左端は卜 ンネル壁面 $(r=R: R / r=1)$ に，右端は無限遠方 $(r$ $=\infty: R / r=0)$ にそれぞれ対応している.この図のプ ロットの方法および，得られる結果は以下のとおりであ る.

(1) 点 5 を不動点として, 計測結果をプロットすると, ○印のようになったとする，2,3,4,5の各点の值を結 ぶ直線が求まるから，これらの点は弾性域にあること， および直線から離れる点 $\mathrm{A}, 1$ は非弾性域にあり, 弾性・ 非弾性域の境界は点 1 と 2 の間にあることがわかる.

(2) 計測の都合で，点 5 の変位をゼロとしたが，点 5 は不動点とは考えられない。 そこで, 無限遠方 $(R / r$ =0）で変位がゼロとなるよう各点の変位量を上方に平 行移動することで補正すると，○印のように各点の絶対 変位量と補正された直線関係が求まる.

(3) 補正された直線と, 縦軸 $(R / r=1.0$ 軸) との交 点の值 $u_{r} /\left.R\right|_{r=R}$ が $p_{0} / 2 G$ に等しいことは式 (23) に おいて明らかである。したがって，かぶり泎 $p_{0}=\gamma H$ を 与えると，せん断弾性係数 $G$ が決定できる.

以上，トンネル掘削前に変位計を設置したとしての議 論であったが，計測は切羽後方で行われることが多く， この場合には前節と同様にFig. 6 を用いて $G$ を補正す る必要がある.

b）青函トンネルにおける計測結果の解析例 ${ }^{8)}$

青函トンネル吉岡方 $25 \mathrm{~km} 965 \mathrm{~m}$ (地山は黒松内層砂 質泥岩で $\gamma=1.85 \mathrm{tf} / \mathrm{m}^{2}$ ，またトンネルは海面下 $240 \mathrm{~m}$, 海底下 $100 \mathrm{~m}$ に位置する）において, Fig. 8 のように先 進導坑から前もつて地中変位計を設置し, 本坑掘削時の 変位計測が行われた. Fig. 9 は本坑を半径 $5.65 \mathrm{~m}$ の円 形断面と仮定して, 計測結果から求まる $u_{r} / R \sim R / r$ 関係である.この図による解析の結果は以下のようであ る.

(1) 壁面で計測されるひずみは約 $0.8 \%$ であり，岩 石の破壊ひずみから考えると, 周辺地山は弾性的に挙動 


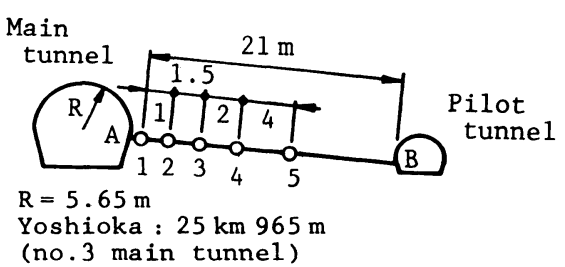

Fig. 8 Installation of an extensometer at the Seikan Tunnel.

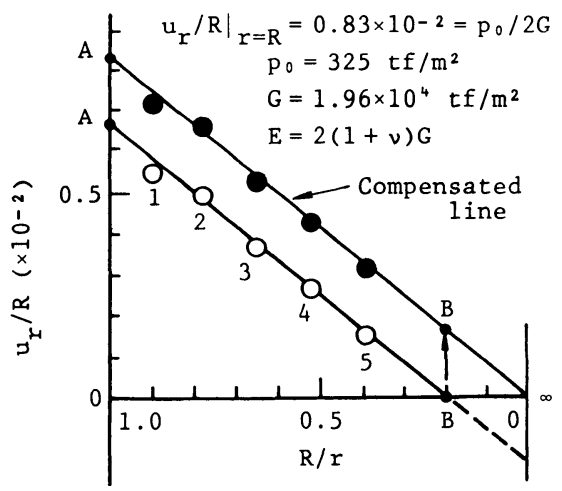

Fig. 9 Evaluation of measured results at the main tunnel of Seikan Tunnel.

していると推定される.

(2) 補正された直線と縦軸との交点の值は $0.83 \times$ $10^{-2}$ であるから， $p_{0}=325 \mathrm{tf} / \mathrm{m}^{2}$ を与えると， $G=1.96$ $\times 10^{4} \mathrm{tf} / \mathrm{m}^{2}$ と推定できる， $\nu=0.3$ と仮定すれば，ヤン グ率は $E=5.10 \times 10^{4} \mathrm{tf} / \mathrm{m}^{2}$ となる.なお，この場合に はトンネル掘削以前に変位計を設置してあったから $G$ の補正を行う必要はない.

(3) Fig. 9 から明らかなように, 先進導坑の壁面 B は 不動点ではなく, B点では $u_{r} / R=1.7 \times 10^{-3}$, すなわち, $u_{r}=1.0 \mathrm{~cm}$ 本坑方向に移動していることになる.

（2）初期地山応力が二次元の場合

a) 解析方法
2. で示す Fig.1のように, 二次元応力場の理想弾性 地山内に半径 $R$ の円形トンネルを掘削する場合を考え ると, 変位 $u_{r}, u_{\theta}$ をトンネル半径 $R$ で除したものは式 ( 5 )，（6）功次のように求まる.

$$
\begin{aligned}
\frac{u_{r}}{R}= & \frac{\sigma_{1}}{4 G}\left\{(1+\alpha)\left(\frac{R}{r}\right)+(1-\alpha)\left[(1+\chi)\left(\frac{R}{r}\right)\right.\right. \\
& \left.\left.-\left(\frac{R}{r}\right)^{3}\right] \cos 2 \theta\right\} \ldots \ldots \ldots \ldots \ldots \ldots \ldots \ldots \ldots \ldots \ldots \ldots \ldots \ldots \ldots
\end{aligned}
$$

$$
\frac{u_{\theta}}{R}=\frac{\sigma_{1}}{4 G}(1-\alpha)\left[(\chi-1)\left(\frac{R}{r}\right)+\left(\frac{R}{r}\right)^{3}\right] \sin 2 \theta \cdots
$$

地中変位計を Fig. 10 のようにトンネル径方向にのみ 設置したとする．この場合，接線方向変位成分 $u_{\theta}$ が計 測結果に与える影響は微小であり，計測変位量は径方向 変位成分 $u_{r}$ で近似できるから，式（24）のみを考えれ ばよい。

さて, 周辺地盤のすべてがトンネル掘削によって弾性 的に挙動したと考え得る場合，式（24）において， $u_{r} / R$ が最大值をとるのはトンネル壁面 $r=R$ で，かつ 最大主応力方向 $\theta=0^{\circ}$ のときである. すなわち,

$$
\left(\frac{u_{r}}{R}\right)_{\max }=\left.\frac{u_{r}}{R}\right|_{r=R} ^{\theta=0^{\circ}}=\frac{\sigma_{1}}{4 G}[(1+\alpha)+(1-\alpha) \chi] \cdots(26)
$$

この最大値で式 (24) の両辺を除すことで $\nu, \alpha, \theta$ を パラメーターとした，規準化された変位曲線定規 $\left(u_{r} / R\right) /\left(u_{r} / R\right)_{\max } \sim R / r$ 関係が Fig. 11 の実線で表わす

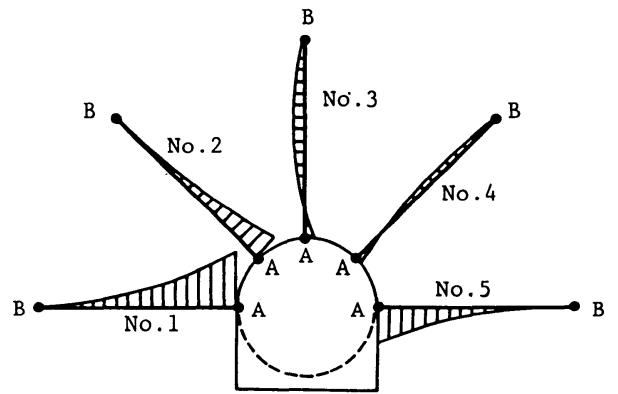

Fig. 10 Installation of extensometer in the surrounding ground.
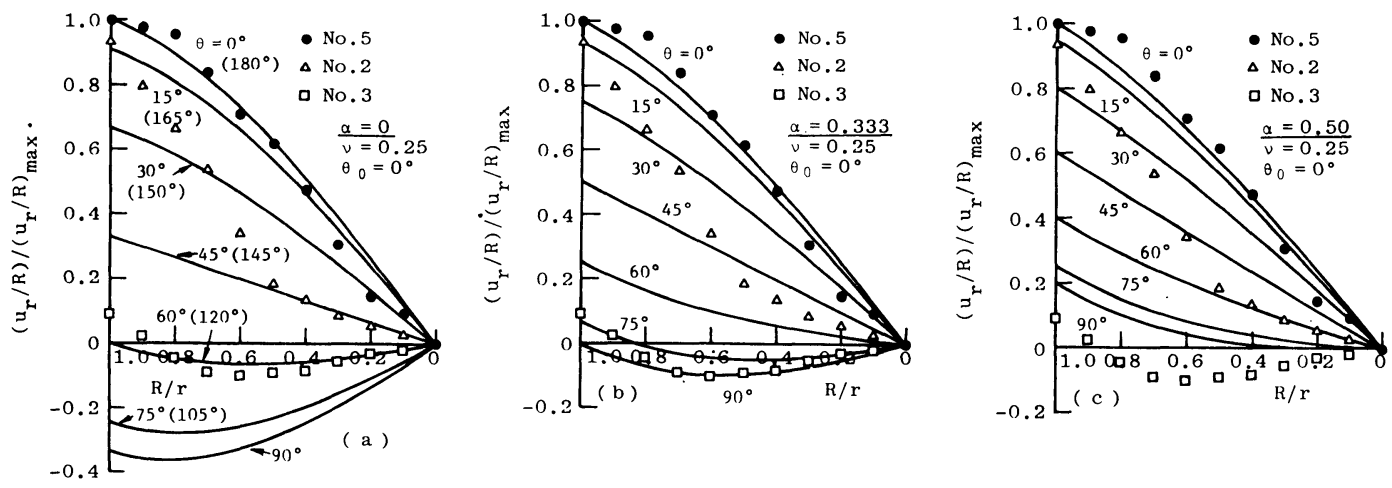

Fig. 11 Normalized relation of $\left(u_{r} / R\right) /\left(u_{r} / R\right)_{\max } \sim R / r$. (a) $\quad \alpha=0$, (b) $\quad \alpha=1 / 3=0.333$, (c) $a=1 / 2=0.5$ 
ように準備できる。なお，Fig.11 はポアソン比 $\nu=$ 0.25 に対して，(a)，(b)，(c) は $\alpha=0,1 / 3,1 / 2$ にそれ ぞれ対応している. また, 図中の $\theta$ の值は最大主応力 $\sigma_{1}$ 之所定の方向の成す角度であり, プロット点は前述 したTable 1 のトンネルで計測された地山内変位計測結 果で, 後述する解析方法の説明で利用する.

しかしながら，ここで留意すべきことは，最大值を示 す計測方向が必ずしも最大主応力方向と一致しているわ けではない.さらに，地山の全領域が弾性挙動を示すと も限らない.このような一般的な場合には, 最大値を与 える計測方向と最大主応力方向との成す角度 $\theta_{0}$ と $r_{e}$

$\left(r_{e}\right.$ : 弾性・非弾性領域の境界の距離 $\left.r\right)$ 以梁では弾 性挙動を示していると考えられる場合には $R / r_{e} \sim 0$ の 範囲の計測値を用いて解析する必要がある.すなわち， 規準化曲線を求めるためには, 式 (24) の両辺を

$$
\begin{aligned}
\left.\left(\frac{u_{r}}{R}\right)\right|_{r=r_{e}} ^{\theta=\theta_{0}}= & \frac{\sigma_{1}}{4 G}\left\{(1+\alpha)\left(\frac{R}{r_{e}}\right)+(1-\alpha)\left[(1+\chi)\left(\frac{R}{r_{e}}\right)\right.\right. \\
& \left.\left.-\left(\frac{R}{r_{e}}\right)^{3}\right] \cos 2 \theta_{0}\right\} \ldots \ldots \ldots \ldots \ldots \ldots(27)
\end{aligned}
$$

で除す必要がある．後で示す青函トンネルにおける計測 結果の解析はこのような一般的な場合に相当している.

Table1のトンネルで, Fig.10のような地山内計測を 実施したところ，Fig.12(a) の結果を得たとする．この 結果からいかに地山内応力, 地山の力学定数を決定する かを順次説明する.

(1) Fig. 12(a) は最深計測点を不動点と考え, プロッ トしたものであるから， $R / r<0.5$ の深い部分の測定値 を用いて外挿することで, 無限遠方で変位がゼロとなる ように補正して Fig. 12(b) を求める. 理論上, No.1 と No. 5 は一致すべきであるが，トンネル近傍では違いが みられるものの, $R / r<0.7$ 以深ではほぼ等しい値を示 しているといえる. そこで, 最大值を示す No. 5 計測に よるトンネル壁面の値 $u_{r} /\left.R\right|_{r=R}$ で, すべての計測値を 規準化することで Fig. 12(c) が求まる.なお，この場 合には計測結果の変形モードから, No. 5 計測と No. 3
計測が弾性的に挙動していると判断し，すべての計測値 をNo. 5 計測の $u_{r} /\left.R\right|_{r=R}$ で規準化した.

(2) Fig. 12(c) の規準化された計測値と, 先に準備し た規準化された理論曲線定規 Fig. 11 を比較することで, 応力比 $\alpha$ を決定する.すなわち, No. 5 計測方向が最大 主応力方向 $\left(\theta=0^{\circ}\right)$ に, No. 3 計測方向が最小主応力 方向 $\left(\theta=90^{\circ}\right)$ に一致するものと仮定し, Fig. 11 のよ うに計測値と理論曲線を比較すると, Fig. 11 (b) が最 もよい一致を示していることがわかる. したがって, 応 力比パラメーター $\alpha\left(=\sigma_{3} / \sigma_{1}\right)$ は $1 / 3(0.333)$ 之決定 できる.

(3) しかしながら，最大変位を示すNo. 5 方向が最大 主応力方向に必ずしも一致しているわけではない。たと えば, Fig.11(b) において, No.5 方向が最大主応力方 向であるなら, No. 2 は最大主応力方向から $45^{\circ}$ の方向 にあるべきで, 計測値は $45^{\circ}\left(135^{\circ}\right)$ の理論曲線に一致 すべきであるが，一致はみられない，そこで，(2)で決定 された応力比 $\alpha$ は固定し, No. 5 方向が最大主応力方向 から反時計まわりに $\theta_{0}$ だけ傾いているとして, 式 (24) に $\theta=\theta_{0}$ を代入して求まるトンネル壁面の值 $\left.\left(u_{r} / r\right)\right|_{r=R}$ で式 (23) の両辺を除すことで求まる規準化曲線之計測 変位を比較することで，最適な $\theta_{0}$ を決定する．このよ うに比較検討したところ, 当該トンネルの場合には Fig. 13 のように $\theta_{0}=-7^{\circ}$ が最適であることがわかった. すなわち, 最大主応力はNo. 5 方向の右上方から $7^{\circ}$ 傾 いて作用している．換言すると No.1 方向の左下方から Fig. 14 の実線の応力ベクトルで示すように作用してい ることになる。この場合を以下の議論の便宜上 Case I としておく.

(4) ところが上記の場合, Fig. 13で明らかなように No. 4 の計測結果は説明できない，すなわち，No.4の 結果はNo. 3 の結果と深部で等しく, 最小値を示すから, このことを満足するには, 最小主応力が No. 3 と No. 4 方向の中間, 最大主応力方向は Fig. 14 の点線の応力心゙ クトルのようにNo. 1 方向の左上方 $22.5^{\circ}$ の方向に作用
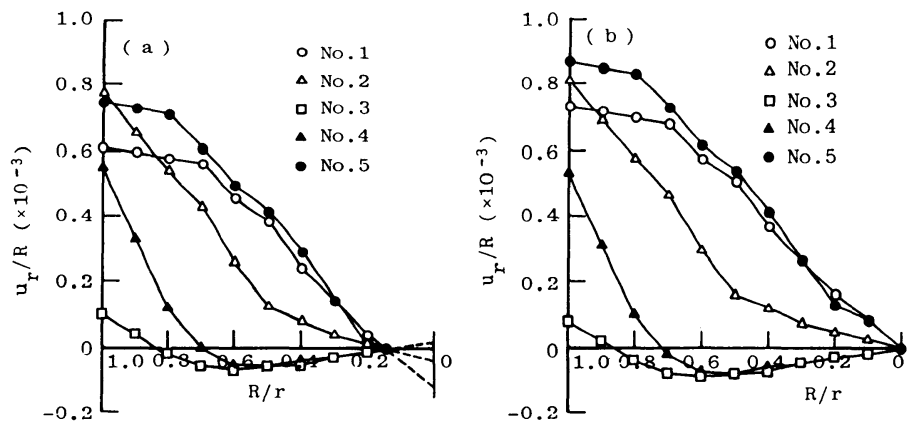

Fig. 12 Measures results, compensation and normalizatio

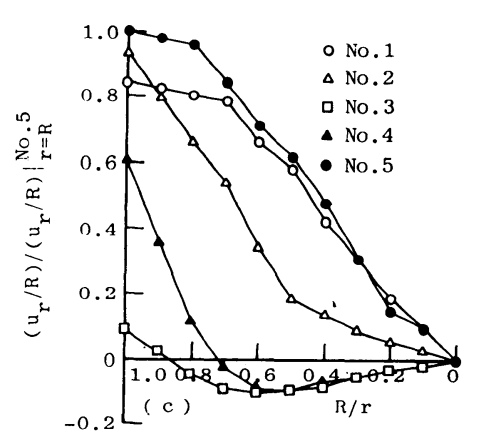

(a) results, (b) compensation, (c) normalization 


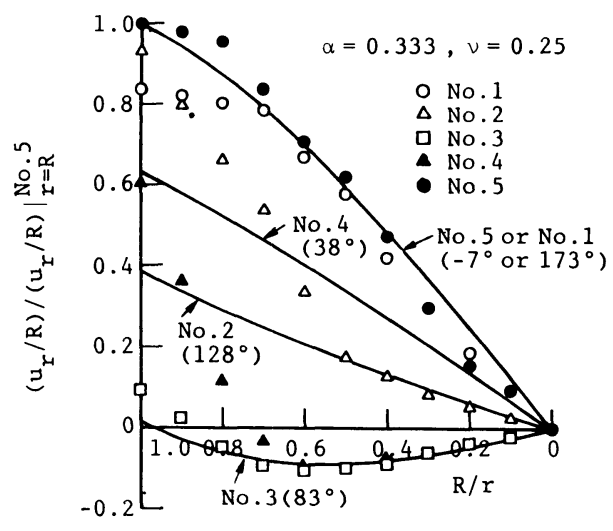

Fig. 13 Normalized relation and evaluation of Case I.

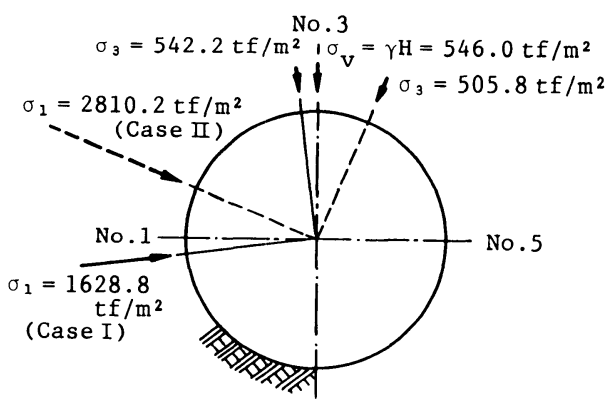

Fig. 14 Maximum and minimum principal stress directions. Case I and Case II.

しなければならないことは容易に推定できる．この場合 の地山内変位挙動を最もよく説明できるのは Fig. 15 の ように $\alpha=0.180$ となるが，No. 2 の結果を説明するこ とはできない。これを Case II とする.

(5) Case I, II において, 主応力比 $\boldsymbol{\alpha}$ と最大主応力 方向 $\theta$ はそれぞれ決定されたから, 式 (18), (19) を 用いて最大, 最小主応力を求めると Case I では, $\sigma_{1}=$ $1628.8 \mathrm{tf} / \mathrm{m}^{2}, \quad \sigma_{3}=542.4 \mathrm{tf} / \mathrm{m}^{2}$, Case II で $\sigma_{1}=2810.2$ $\mathrm{tf} / \mathrm{m}^{2}, \sigma_{3}=505.8 \mathrm{tf} / \mathrm{m}^{2}$ となり, それぞれの応力棈円は Fig. 16 に示すとおりである。これらの結果から，いず れにしても最大主応力はほぼ水平に近いことがわかる.

(6) せん断弾性係数 $G$ は式（24）に上記で求めた諸 量を代入することで決定できる. Fig. 17 は地山内変位 計の各深度での計測值を用いて求めたものである. Case I では $1.0 \sim 1.5 \times 10^{6} \mathrm{tf} / \mathrm{m}^{2}$, Case II では 1.7 $2.5 \times 10^{6} \mathrm{tf} / \mathrm{m}^{2}$ となる. 当該卜ンネルの内空変位から求 めた值はFig. 5 のように $\nu=0.25$ の場合, $G=1.30 \times$ $10^{6} \mathrm{tf} / \mathrm{m}^{2}$ であるから, それとの整合性からいえば Case Iが近いことになる.ただし，この值は切羽の影響を考 慮しておらず, 計測が切羽後方 $0.8 \mathrm{~m}$ で開始されたと すると, 実際のせん断弾性係数は上で求まる值の $30 \%$

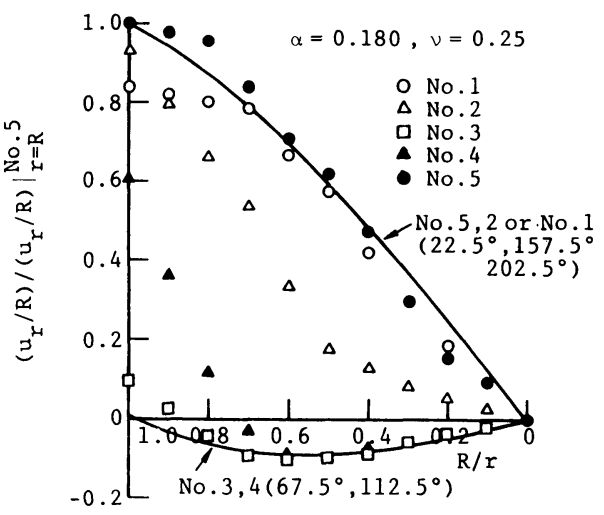

Fig. 15 Normalized relation and evaluation of Case II.

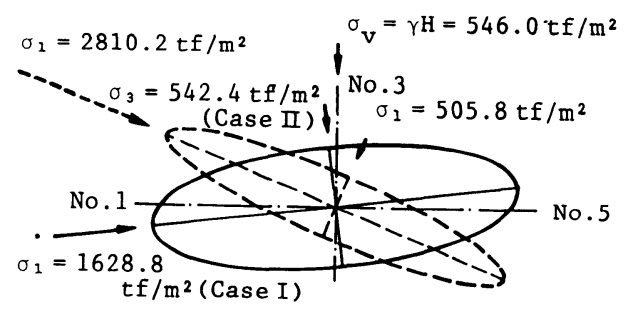

Fig. 16 Stress ellipses.

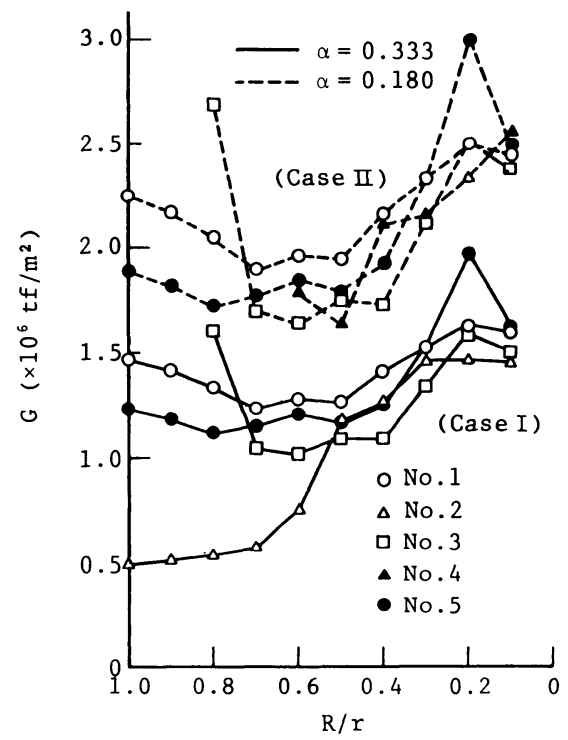

Fig. 17 Shear modulus obtained from the measured results.

程度と見込まなければならない。

(7) (1)〜(3)において， $\alpha, \theta_{0}$ などを計算する場合に， すべての領域が弾性的であると仮定したが，Fig.13の 解析結果より, 非弾性領域は Fig. 18 に示すように推定 することができる.

b）青函トンネルにおける計測結果の解析例 ${ }^{81}$ 


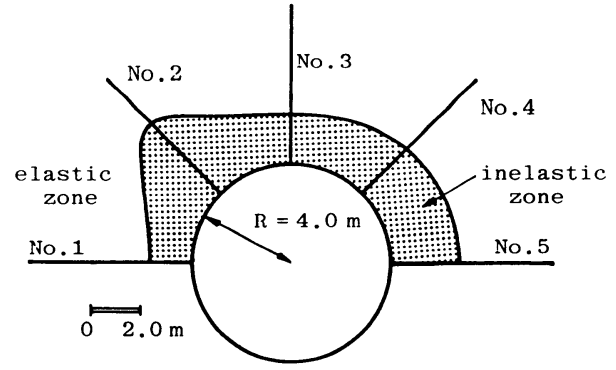

Fig. 18 Inelastic zone developed in surrounding ground.
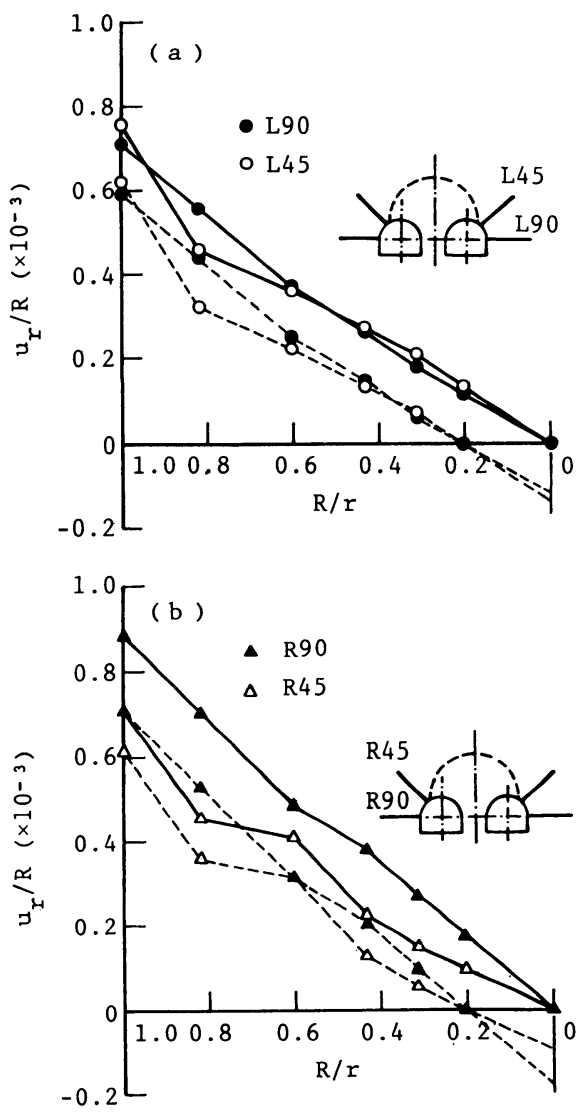

Fig. 19 Measured results at Seikan Tunnel and the compensation.

Fig. 19(a)，(b) の点線で示されるデータは，青函卜 ンネル吉岡方 $25 \mathrm{~km} 650 \mathrm{~m}$ 地点における本坑の側壁導坑 の地山内変位計測結果である.以下に順次主応力の方向, 大きさおよび, 地山のせん断弾性係数を求める.

(1) 無限遠方で変位がゼロとなるように補正する. そ の結果は実線で示してある.

(2) Fig. 19(a), (b) で弾性・非弾性領域の境界と考 えられる $R / r_{e}=0.434$ での最大変位量で規準化すると

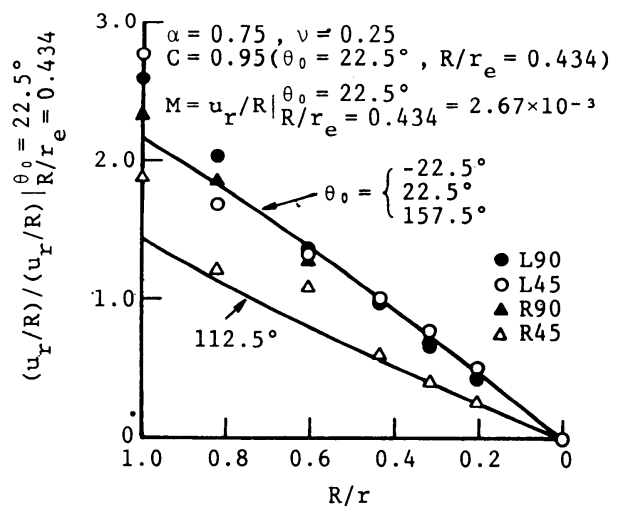

Fig. 20 Normalized relation and evaluation.

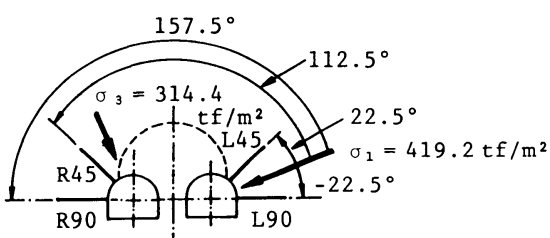

Fig. 21 The maximum and minimum principal stress directions at Seikan Tunnel.

（ただし，(a) 図ではL45 で，(b) 図ではR 90 で規準 化)，Fig.20 となる. 図からわかるように，R90，L90， L45 は同等の変位を示しているから, 最大主応力は L 90 方向から上方 $22.5^{\circ}$ 方向より作用していると考え られる. そこで, 式 (24) に $\alpha=0.75, \theta=\theta_{0}=22.5$ を 代入すると，Fig. 20 中の実線が実測値をよく説明する ことがわかる.

(3) 最大・最小主応力は式 (18) と $\gamma H=325 \mathrm{tf} / \mathrm{m}^{2}$ を 用いることで，Fig. 21 に示すように $\sigma_{1}=325 / 0.775=$ $419.2 \mathrm{tf} / \mathrm{m}^{2}, \quad \sigma_{3}=\alpha \sigma_{1}=314.4 \mathrm{tf} / \mathrm{m}^{2}$ となる.

(4) せん断弾性係数 $G$ は上記で求めた諸量を式 (24) に代入することで， $G=3.79 \times 10^{4} \mathrm{tf} / \mathrm{m}^{2}$ と算出できる. なお, 計測は切羽通過直後に変位計を設置して開始して おり, $50 \%$ の変位を計測したと考えると, 実際のせん 断弾性係数は $G=1.90 \times 10^{4} \mathrm{tf} / \mathrm{m}^{2}$ となり, Fig. 9 の計測 で推定した值 $G=1.96 \times 10^{4} \mathrm{tf} / \mathrm{m}^{2}$ に近い。ただし，ポ アンン比 $\nu$ は 0.25 と仮定している.

(5)この計測結果の場合, $R / r_{e}$ を 0.434 と仮定した が, 解析の結果, 非弾性領域は $R / r=0.6 \sim 1.0$ の範囲 内にあると考えられる。

\section{5. 結 論}

以上，弾性地山と円形トンネルの掘削と仮定したとき の厳密解に基づく, トンネルの変位計測結果の簡易解析 
法を述べた．特に，日常業務となっている内空変位計測 結果を本手法で解析すれば，序論で述べたように支保構 造, 施工の適・不適の判断に供すべきデータが蓄積され るものと期待できる.

本研究の端緒は財団法人大阪土質試験所の岩崎好規氏 との討議によるところが大であり，また本研究に用いた 青函トンネルの計測結果は土木学会青函トンネル土圧研 究委員会に提供されたもので，鉄道建設公団の関係各位 にも併せて謝意を表する.

\section{参考文献}

1) 桜井春輔・武内邦文：トンネル掘削時における変位計測 結果の逆解析法, 土木学会論文報告集, No. 337 , pp. 137 〜145, 1983.

2) たとえば, Savin, G. N. : Stress Concentration Around Holes, translated by E. Gros. Pergamon press, 1961.
3）足立紀尚・矢野隆夫：内空変位計測結果の簡易評価法, 第 22 回土質工学研究発表会講演概要集, pp. 1633 1636, 1987.

4) 久武勝保・稲葉 力・平田篤夫：三次元逆解析のトンネ ル現場への適用, 第 19 回岩盤力学に関するシンポジウム 講演論文集, pp. 291〜295, 1987.

5）足立紀尚・矢野隆夫：トンネル計測結果の簡易評価法, 第 20 回土質工学研究発表会講演概要集, pp. 1557 1560, 1985.

6）足立紀尚・矢野隆夫：トンネル計測結果の簡易評価法, 第 42 回土木学会年次学術講演会, III $-254,1987$.

7）岩崎好規：トンネル工事における計测技術と意義につい て，NATM 工法と施工機材に関する講習会講演概要，日 本建設機械化協会関西支部, pp. 78 93，1981.

8）青函トンネル土生研究調查報告書, 土木学会, pp. 377 384, 1985.

(1987.5.21 • 受付) 